\title{
T lymphocyte activation state in the minor salivary glands of patients with Sjögren's syndrome
}

\author{
M SEGERBERG-KONTTINEN, ${ }^{\text {K }}$ V BERGROTH, ${ }^{1}$ P JUNGELL, \\ M MALMSTRÖM.2 D NORDSTRÖM. I JANE ?' I IMMONEN, AND \\ Y T KONTTINEN ${ }^{1}$
}

From the 'Fourth Department of Medicine, Helsinki University Central Hospital; the 'Institute of Dentistry. Department of Oral Surgery, University of Helsinki; and the 'Department of Ophthalmology, Helsinki University Central Hospital, Helsinki, Finland

SUMMARY Local lymphoplasmacytoid infiltration of the diseased exocrine glands is a cardinal sign of Sjögren's syndrome (SS). The state of T lymphocyte activation present in these local infiltrations was studied by three different techniques: determination of interleukin 2 (IL2) receptor (Tac) on cell surface membrane; autoradiography combined with immunoperoxidase staining of $\mathrm{T}$ cell epitopes; and electron microscopic analysis of the lymphoblast subclasses. Although 64 (SEM 4)\% of the local inflammatory cells expressed Ia antigen, only 4 (SEM 1) \% of them displayed the $\mathrm{T}$ cell activation antigen Tac. Autoradiography-immunoperoxidase double labelling showed that less than $1 \%$ of all $\mathrm{T}$ cells in situ were $\left[{ }^{3} \mathrm{H}\right]$ thymidine incorporating blasts. This finding suggests that although $\mathrm{T}$ lymphocyte is the dominant cell in situ, only a few of these cells have passed the $G_{0} / G_{1}$ interphase, and even fewer have been pushed to the $S$ phase of the cell cycle by IL2. Transmission electron microscopy showed that few T blasts were present, even though there were many plasma cells. This result further confirms the impression that only a minor $\mathrm{T}$ cell subpopulation in situ is blast transformed despite the fact that many of the local $\mathrm{T}$ lymphocytes in the diseased salivary glands in SS are Ia positive.

Sjögren's syndrome (SS) is an autoimmune exocrinopathy clinically characterised by xerostomia and keratoconjunctivitis sicca. ${ }^{12}$ SS is characterised by lymphocytoid cell infiltration of the lachrymal and salivary glands ${ }^{3-5}$; therefore the composition of this infiltration has been analysed in many cytoadherence, histochemical, and immunohistological studies. ${ }^{6-13}$ The presence of $B$ lymphocytes and plasma cells in situ has been well recorded. ${ }^{7-10} \mathrm{~T}$ lymphocytes, however, especially those belonging to the $\mathrm{T}^{+}{ }^{+}$inducer/helper subset, seem to be the predominant cells in situ. ${ }^{11-1.3}$ In this work we studied the activation state of T lymphocytes in situ in the diseased glands in SS.

The cardinal feature of SS is a chronic mononuclear cell infiltration of the exocrine glands. Many of the local lymphoid cells are of B cell origin and there is much evidence indicating active $B$ cell involvement in the pathogenesis of SS. ${ }^{7-10}$ This

Accepted for publication 11 April 1987.

Correspondence to Dr M Segerberg-Konttinen. Fourth Department of Medicine. Helsinki University Central Hospital, Unioninkatu 38. SF-(K)170 Helsinki. Finland. includes hypergammaglobulinaemia, autoantibodies, demonstration of plasma cells in situ, an active immunoglobulin and rheumatoid factor synthesis in diseased glandular tissue, and the development of B cell derived malignancies in SS. ${ }^{14}$ In most patients with SS, however, T lymphocyte is the predominant immune inflammatory cell in the diseased salivary glands. ${ }^{11-1.3}$ There is little information on the state of activation of this lymphocyte subset in situ. We therefore studied the state of $\mathrm{T}$ cell activation in the labial salivary glands of patients with SS by three different techniques to assess Tac expression, lymphocyte ultramorphology, and DNA synthesis.

\section{Patients and methods}

PATIENTS AND BIOPSIES

Clinical characteristics of the patients studied are given in Table 1. In addition, labial salivary glands were also obtained from four patients without SS (patients 9-12; Table 1) and without any inflammatory systemic or local inflammatory disease. 
Table 1 Clinical data of the patients studied

\begin{tabular}{|c|c|c|c|c|c|c|}
\hline Patient No & Age & Sex & Diagnosis & Therapy & $\begin{array}{l}\text { Schirmer's } \\
\text { test }\end{array}$ & $\begin{array}{l}\text { Focus } \\
\text { score }\end{array}$ \\
\hline 1 & 31 & $\mathbf{F}$ & $1^{\circ} \mathrm{SS}$ & None & $4 / 5$ & $3 \cdot 5$ \\
\hline 2 & 41 & $\mathbf{F}$ & $1^{\circ} \mathrm{SS}$ & None & $3 / 6$ & 1 \\
\hline 3 & 53 & $\mathbf{F}$ & $1^{\circ} \mathrm{SS}$ & None & $3 / 0$ & 9 \\
\hline 4 & 28 & $\mathbf{F}$ & $2^{\circ} \mathrm{SS} / \mathrm{RA}$ & NSAID & $5 / 2$ & 2 \\
\hline 5 & 54 & $\mathbf{F}$ & $2^{\circ} \mathrm{SS} / \mathrm{PMR}$ & Prednisone & $0 /()$ & 2 \\
\hline 7 & 30 & $\mathbf{F}$ & $1^{\circ} \mathrm{SS}$ & None & $(0 / 0$ & $4 \cdot 2$ \\
\hline 8 & 56 & $\mathbf{F}$ & $1^{\circ} \mathrm{SS}$ & None & $1 / 0$ & $4 \cdot 4$ \\
\hline 9 & 32 & $\mathbf{M}$ & Fibrositis & Nonc & $19 / 22$ & 0 \\
\hline 10 & 39 & $\mathbf{F}$ & Iatrogenic & None & $0 / 0$ & 0 \\
\hline 11 & 74 & $\mathbf{F}$ & Iatrogenic & None & ND & $0 \cdot 3$ \\
\hline 12 & 46 & $\mathbf{F}$ & Psychogenic & None & $20 / 24$ & 0 \\
\hline
\end{tabular}

$1^{\circ} \mathrm{SS}=$ primary Sjögren's syndrome; $2^{\circ} \mathrm{SS}=$ secondary Sjögren's syndrome; RA=rheumatoid arthritis; PMR=polymyalgia rheumatica; NSAID = non-steroidal anti-inflammatory drug.

Six labial salivary glands were removed from each patient through a $2 \mathrm{~cm}$ long horizontal incision on the inside of the lower lip $1 \mathrm{~cm}$ from the vermilion border to the right of the midline. The local anaesthesia was $1.8 \mathrm{ml}$ of Citanest-Octapressin.

Immediately after removal two glands processed for transmission electron microscopy were fixed with cold $\left(4^{\circ} \mathrm{C}\right) 1.5 \%$ phosphate buffered glutaraldehyde for one hour, washed, then postfixed in cold $1.5 \%$ osmium acid for one hour. After alcohol dehydration the specimens were treated twice with propylene oxide and embedded in Epon 812. Two glands were immediately embedded in OCT compound (Lab-Tek Products, Division Miles Laboratories, Elkhart, IN), snap frozen, and stored at $-20^{\circ} \mathrm{C}$ for immunohistochemical lymphocyte activation marker profile analysis. Immediately after removal two glands processed for autoradiography-avidin-biotin-peroxidase complex (ABC) double labelling were put into RPMI 1640 solution containing $111 \mathrm{kBq} / \mathrm{ml}$ or $\left[{ }^{3} \mathrm{H}\right]$ thymidine (185
$\mathrm{MBq} / \mathrm{mmol}$; Radiochemical Centre, Amersham UK) and $0.5 \mathrm{mg} / \mathrm{ml}$ of thymidine phosphorylaseinhibitor 5-nitrouracil, incubated at $37^{\circ} \mathrm{C}$ for two hours, and snap frozen in OCT.

\section{H I S T O C H E M I S T R Y}

Cryostat sections $6 \mu \mathrm{m}$ thick were prepared and fixed in cold $\left(4^{\circ} \mathrm{C}\right)$ acetone for 5 minutes gnco preparation for immunostaining. The sections weet washed in phosphate buffered saline $(0 \cdot 1 \mathrm{M}, \mathrm{pH} 7 \mathbf{3})$ and stained with monoclonal antibodies using the $\mathrm{ABC}$ method introduced by Hsu et al. ${ }^{15}$ Technica details and staining and slide controls have beeno described in detail elsewhere. ${ }^{16}$ The preparationso were studied with several monoclonal antibodies given in Table 2. As a further control we used? inappropriate mouse $\mathrm{IgG}$ myeloma protein $\mathrm{NSI}^{3}$ from P3 $\times 63 N S 1$ line (Cappel Laboratories Cochranville, PA) instead of the specific primary antibodies. Exogenous, peroxidase positive, speci $\frac{\Omega}{2}$ fically stained cells were brown and thus readilyo

Table 2 Characteristics of monoclonal antibodies used in this study

\begin{tabular}{|c|c|c|c|}
\hline $\begin{array}{l}\text { Monoclonal } \\
\text { antibody }\end{array}$ & Specificity & Reference & D \\
\hline $\begin{array}{l}\text { OKT11 } \\
\text { OKT4 } \\
\text { OKT8 } \\
\text { OKM1 } \\
\text { pan-B } \\
\text { OKIa } \\
\text { Tac } \\
\text { OKT9 } \\
\text { 4F2 }\end{array}$ & $\begin{array}{l}\text { Total } T \text { cells } \\
\text { Helper/inducer } T \text { cells } \\
\text { Suppressor/cytotoxic } T \text { cells } \\
\text { Monocytes, null cells, granulocytes } \\
\text { B cells } \\
\text { Activated T cells, B cells, monocytes } \\
\text { Activated lymphocytes ( } T \text { cell } \\
\text { growth factor receptor) } \\
\text { Activated lymphocytes (transferrin receptor } \\
\text { early haematopoietic stem cells) } \\
\text { Activated lymphocytes, monocytes }\end{array}$ & $\begin{array}{l}17 \\
18 \\
19 \\
20 \\
21 \\
22 \\
23,24 \\
25 \\
26\end{array}$ & 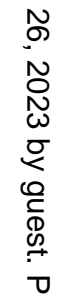 \\
\hline
\end{tabular}




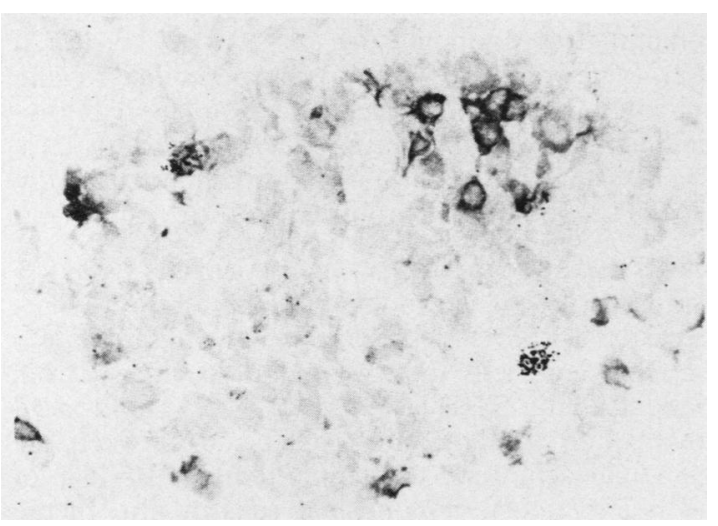

Fig. 1 Autoradiography-avidin-biotin-peroxidase complex (ABC) double labelling of $\mathrm{T}^{+}$cells. [ [ $\mathrm{H}$ ] Thymidine labelled blast cells visualised with autoradiography contain black grains over the nucleus.

distinguishable from unstained cells under a light microscope. The cells analysed by light microscopy were counted from $6 \mu \mathrm{m}$ thick haematoxylin counterstained tissue sections with an ocular counting square (20 squares $\times 20$ squares) and an oil immersion objective $(\times 1000$ magnification $)$. Standard error of the mean was used to expression dispersion, and the significance of the differences between mean values was determined with the Mann-Whitney test.

\section{AUTORADIOGRAPHY - ABC DOUBLE}

LAB ELLING

After incorporation of $\left[{ }^{3} \mathrm{H}\right]$ thymidine and $\mathrm{ABC}$ staining some OKT4, OKT8, and Tac stained slides were further processed for autoradiography. They were dipped in NTB2 nuclear track emulsion (Eastman Kodak Co, Rochester, NY), exposed in darkness for 12 days, developed (Developer D-76; Eastman Kodak) for four minutes, and fixed (Rapid Fix; Eastman Kodak) before mounting. ${ }^{27}$ Cells were

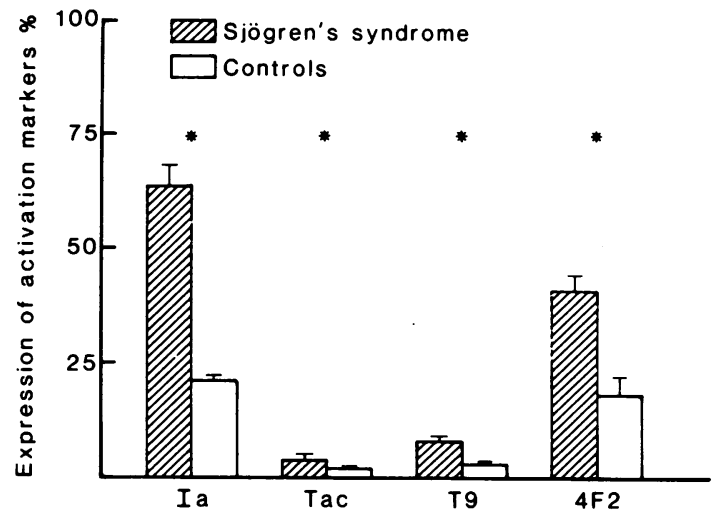

Fig. 2 Activation marker profile assay shows that the lymphocyte activation state in minor salivary glands differs between patients with Sjögren's syndrome and healthy controls. ${ }^{*} p<0 \cdot 01$, Mann-Whitney test.

regarded as $\left[{ }^{3} \mathrm{H}\right]$ thymidine labelled when they contained numerous grains over the cell nucleus (Fig. 1). The results of autoradiography-ABC double labelling are given as a percentage of all $\left[{ }^{3} \mathrm{H}\right]$ thymidine incorporating blasts.

\section{TRANSMISSION ELECTRON MICROSCOPY}

Ultrathin sections prepared from specimens embedded in Epon were heated to $60^{\circ} \mathrm{C}$, after which the sections were stained with uranyl acetate and lead citrate for the electron microscopic study (Jeal CX-100 transmission electron microscope). Ultramorphologically, cells were regarded as lymphoblasts if they were greater than $10 \mu \mathrm{m}$ in diameter and if the nucleus: cytoplasm ratio was less than $0 \cdot 5$; cells were classified as T blasts and plasma cells according to the criteria of Ishikawa and Ziff. ${ }^{28}$

\section{Results}

STA INING CONTROLS

The staining and slide controls indicated the speci-

Table 3 The intensity, but not the composition, of the cellular infiltrates differs in minor salivary glands of patients with Sjögren's syndrome compared with those of healthy controls

\begin{tabular}{|c|c|c|c|c|c|c|}
\hline \multirow{2}{*}{$\begin{array}{l}\text { Source of } \\
\text { biopsy specimen }\end{array}$} & \multirow[t]{2}{*}{ Focus score } & \multicolumn{3}{|c|}{ All inflammatory cells (\%) } & \\
\hline & & $T 11$ & $T 4$ & $T 8$ & $M I$ & $B$ \\
\hline $\begin{array}{l}\text { Patients with SS } \\
\text { Controls } \\
\text { p (Mann-Whitney's U test) }\end{array}$ & $\begin{array}{l}3 \cdot 5(0 \cdot 9)^{\dagger} \\
0 \cdot 1(0 \cdot 1) \\
*\end{array}$ & $\begin{array}{l}67(4) \\
53(3) \\
\text { NS }\end{array}$ & $\begin{array}{l}45(3) \\
37(2) \\
\text { NS }\end{array}$ & $\begin{array}{l}21(2) \\
13(1) \\
\text { NS }\end{array}$ & $\begin{array}{l}7(1) \\
6(1) \\
\text { NS }\end{array}$ & $\begin{array}{l}12(3) \\
8(3) \\
\mathrm{NS}\end{array}$ \\
\hline
\end{tabular}

${ }^{*} \mathrm{p}<0 \cdot 01 ; \mathrm{NS}=$ not significant.

+ Values are mean (SEM). 
ficity of the staining and showed that the inhibition of endogenous peroxidase was successful. Staining for endogenous peroxidase alone showed that the proportion of macrophages and monocytes was less than $10 \%$ of all inflammatory cells in situ in labial salivary glands. $\mathrm{T} 4^{+}$inducer/helper $\mathrm{T}$ lymphocytes were the predominant cells (Table 3 ). Although there was a more intense cellular inflammation in the patients with SS than in those without focal sialadenitis, the composition of the sparse diffuse infiltrates was similar in both (Table 3 ).

\section{ACTIVATION MARKER PROFILE ASSAY}

The proportions of $\mathrm{Ia}^{+}, \mathrm{Tac}^{+}, \mathrm{T}^{+}$, and $4 \mathrm{~F} 2^{+}$cells were higher in the diseased salivary glands than in normal salivary glands (Fig. 2). The proportion of $\mathrm{Ia}^{+}$and $4 \mathrm{~F}^{+}$cells was higher than that of $\mathrm{Tac}^{+}$and $\mathrm{T}^{+}$cells both in patients with SS and controls (Fig. 2).

\section{AUTORADIOGRAPHY - ABC DOUBLE}

L A B E L L I N G

The labelling index of the inflammatory mononuclear cells in situ in the salivary glands of patients with SS was less than $1 \%$. Most of the $\left[{ }^{3} \mathrm{H}\right]$ thymidine incorporating blast cells belonged to the $\mathrm{T}^{+}$subset (69 (SEM 3)\%), whereas only $26(2) \%$ of the $\left[{ }^{3} \mathrm{H}\right]$ thymidine incorporating blasts in situ were from the $\mathrm{T}^{+}$subset. The $\mathrm{T} 4 / \mathrm{T} 8$ ratio, calculated from the proportion of the respective $T$ cell subsets in all the

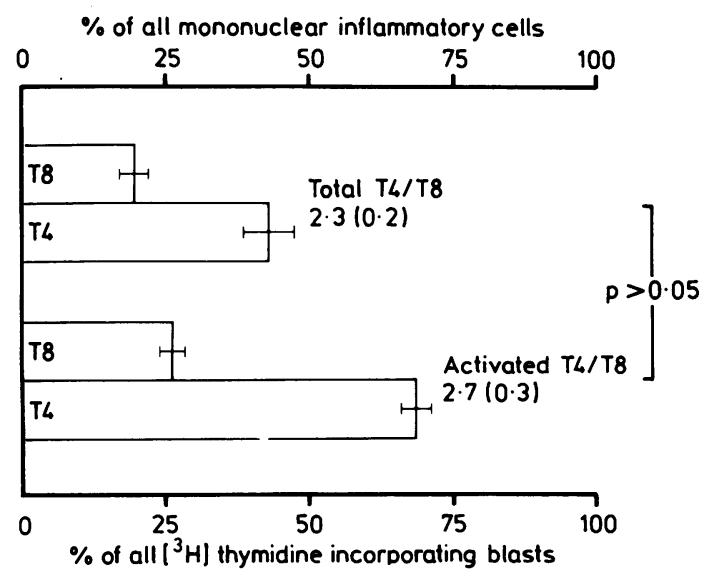

Fig. 3 Comparison of the immunoregulatory T4/T8 ratios calculated for all inflammatory mononuclear cells and for the $\left.{ }^{3} \mathrm{H}\right]$ thymidine incorporating blast cell fraction. Although the latter comprised only a minor fraction (labelling index about 1\%) of all the inflammatory mononuclear cells, there was no significant difference between the total and activated T4/T8 ratios. Ratios are given as mean (SEM). inflammatory mononuclear cells, was 2.3 (SEM $0 \cdot 2)$. The ratio was surprisingly similar to the? activated T4/T8 ratio calculated from the $\left[{ }^{3} \mathrm{H}\right]$ thy- $\overrightarrow{\vec{F}^{*}}$ midine incorporating blast cell fraction $\left(2 \cdot 3(0 \cdot 2) v_{-}^{9}\right.$ $2 \cdot 7(0 \cdot 3))$ (Fig. 3). Normal glands contained hardly응 any $\left[{ }^{3} \mathrm{H}\right]$ thymidine incorporating blasts.

TRANSMISSION ELECTRON MICROASSAY Transmission electron microscopy showed onlyo occasional $\mathrm{T}$ blasts (less than $1 \%$ of all inflammatory mononuclear cells in situ) in the specimens from? patients with SS. Plasma cells were found peri- $\vec{\omega}$ pherally to the lymphocyte foci and between theo glandular acini, and they formed about $10-15 \%$ of all inflammatory mononuclear cells in situ. In the control slides normal salivary glands contained? hardly any $\mathrm{T}$ blasts or plasma cells.

\section{Discussion}

The active involvement of $\mathrm{T}$ lymphocytes in the local pathogenetic mechanisms in SS has beenfs suggested by higher percentages of $\mathrm{Ia}^{+}$lymphocytes? in salivary glands than those in peripheral blood lymphocytes of the same patients. ${ }^{11} \mathrm{We}$ also detected many $\mathrm{Ia}^{+}$cells in situ, but it should be remembered that many other cells-such as ${ }_{0} \mathrm{~B} \times \overrightarrow{0}$ lymphocytes, plasma cells, monocytes, macs-phages, dendritic cells, and even some residềit cells-may display Ia. Surprisingly, immunohisto chemical findings showed low Tac expression confirming the earlier findings of Fox et al. ${ }^{2}$ Furthermore, because interleukin 2 receptor hasD recently been reported on B cells and macro phages, ${ }^{24}$ it is impossible, in the absence of double marker studies, to state that all interleukin 25 receptor bearing cells are $T$ cells. The low per centage of IL2 receptor carrying cells in situ however, might have been due to the blocking of immunoreactive epitopes by receptor bound IL 2 ? This was refuted by experiments in which we used $\left[{ }^{3} \mathrm{H}\right]$ thymidine to assess the proportion of $\mathrm{T}$ cellsi that synthesised DNA in the diseased salivary glands 3 of patients with $\mathrm{SS}^{27}$; less than $1 \%$ of all locab lymphocytes carrying $\mathrm{T}$ cell markers were $\left[{ }^{3} \mathrm{H}\right]$ thy $\frac{\text { D }}{7}$ midine incorporating blasts.

Resting lymphocytes change morphologically. upon activation. Furthermore, plasma blasts ands plasma cells show ultramorphological characteristics distinct from those of $\mathrm{T}$ cell derived activated blasts Our electron microscopic findings on the rarity of lymphoblasts with $\mathrm{T}$ cell characteristics, in contrask with those with plasma blast/plasma cell character istics, strengthen the conclusion based on the immunohistochemical findings for Tac expression and on the autoradiographical findings for $D N A-$ synthesis. 
Active B cell involvement in the aetiopathogenesis of SS is amply recorded, but recent observations using monoclonal antibodies to detect lymphocytes with $\mathrm{T}$ cell phenotype have shown this to be the predominant immune inflammatory cell in situ. According to our findings, based on observations made with three different assays, only a minor fraction of these $\mathrm{T}$ cells, though Ia positive, are blast transformed. This may be related to the chronicity of the disease and does not necessarily imply that most of the local $\mathrm{T}$ lymphocytes are innocent bystanders. In any case, $T$ lymphocyte activation and blast transformation seem to be more extensive in glandular tissue in SS than in normal control glands.

Supported by the Sigrid Juselius Foundation and the Linda Gadd Foundation. Dr Y T Konttinen was financially supported by a senior research fellowship from the Finnish Rheumatism Foundation.

\section{References}

1 Talal N. Sjögren's syndrome and connective tissue disease with other immunologic disorders. In: McCarty D J, ed. Arthritis and allied conditions. Philadelphia: Lea and Febiger, 1985: 1037-51.

2 Fox R I, Robinson C A, Curd J G, Kozin F, Howell F V. Sjögren's syndrome. Proposed criteria for classification. Arthritis Rheum 1986; 29: 577-85.

3 Morgan W S, Castleman B. A clinicopathologic study of 'Mikulicz's disease'. Am J Pathol 1953; 29: 471-503.

4 Chisholm D M, Mason D K. Labial salivary gland biopsy in Sjögren's disease. J Clin Pathol 1968; 21: 656-60.

5 Daniels T E. Labial salivary gland biopsy in Sjögren's syndrome. Assessment as a diagnostic criterion in 362 suspected cases. Arthritis Rheum 1984; 27: 147-86.

6 Chused T M, Hardin J A, Frank M M, Green I. Identification of cells infiltrating the minor salivary glands in patients with Sjögren's syndrome. J Immunol 1974; 112: 641-8.

7 Tannenbaum H. Pinkus G S, Anderson L G, Schur $P$ H. Immunologic characterization of the mononuclear cell infiltrates in rheumatoid synovia, in rheumatoid nodules, and in lip biopsies from patients with Sjögren's syndrome. Arthritis Rheum 1975: 18: 305-14.

8 Konttinen Y T. In situ characterization of the cellular infiltrate in labial and palatine glands in Sjögren's syndrome. Scand $J$ Rheumatol 1981; 10: 321-30.

9 Anderson L G. Cummings N A, Asofsky R, et al. Salivary gland immunoglobulin and rheumatoid factor synthesis in Sjögren's syndrome. Natural history and response to treatment. Am J Med 1972: 53: 456-63.

10 Talal N, Sylvester R A, Daniels T E, Greenspan J S, Williams P C Jr. T and B lymphocytes in peripheral blood and tissue lesions in Sjögren's syndrome. J Clin Invest 1974; 53: 180-9.

11 Fox R I, Carstens S A, Fong S, Robinson C A, Howell F. Vaughan $\mathrm{J} \mathrm{H}$. Use of monoclonal antibodies to analyze peripheral blood and salivary gland lymphocyte subsets in Sjögren's syndrome. Arthritis Rheum 1982; 25: 419-26.

12 Adamson T C III, Fox R I, Frisman D M, Howell F V. Immunohistologic analysis of lymphoid infiltrates in primary
Sjögren's syndrome using monoclonal antibodies. $J$ Immunol 1983; 130: 203-8.

13 Kilpi A, Konttinen Y T, Malmström M, Bergroth V, Reitamo $\mathrm{S}$, Helve T. Immunocompetent cells in labial salivary glands in secondary Sjögren's syndrome associated with SLE. J Oral Pathol 1983; 12: 465-72.

14 Konttinen $Y T$, Segerberg-Konttinen $M$, Bergroth $V$, Malmström M. Pathogenesis of Sjögren's syndrome. First international seminar on Sjögren's syndrome, Copenhagen 1986. Scand J Rheumatol [Suppl] 1986; 61: 61-6.

15 Hsu S M, Raine L, Fanger H. Use of avidin-biotin-peroxidase complex $(\mathrm{ABC})$ in immunoperoxidase techniques: a comparison between $\mathrm{ABC}$ and unlabelled antibody (PAP) procedures. J Histochem Cytochem 1981; 29: 577-80.

16 Konttinen Y T, Bergroth V, Nordström D, Segerberg-Konttinen M. Seppälä K. Salaspuro M. Lymphocyte activation in vivo in the intestinal mucosa of patients with Crohn's disease. $J$ Clin Lab Immunol 1987: 22: 59-63.

17 Verbi W, Greaves M F,. Schneider C, et al. OKT11 and OKT11A: monoclonal antibodies with pan $\mathrm{T}$ reactivity which block sheep erythrocyte receptors on T cells. Eur J Immunol 1982; 12: 81-6.

18 Reinherz E L. Kung P C, Goldstein G, Schlossman S F. Further characterization of the human inducer $\mathrm{T}$ cell subset defined by monoclonal antibody. J Immunol 1976; 123: 2894-6.

19 Reinherz E L, Kung P C, Goldstein G, Levey R H, Schlossman S F. Discrete stages of human intrathymic differentiation: analysis of normal thymocytes and leukemic lymphoblasts of Tcell lineage. Proc Natl Acad Sci USA 1980; 77: 1588-92.

20 Breard J, Reinherz E L, Kung P C, Goldstein G, Schlossman S F. A monoclonal antibody reactive with human peripheral blood monocytes. J Immunol 1980; 124: 1943-8.

21 Stein M, Gerdes J, Mason D Y. The normal and malignant germinal centre. Clin Haematol 1982; 11: 531-59.

22 Reinherz E L, Kung P C, Pesando J M, Ritz J, Goldstein G, Schlossman $\mathrm{S} F$. Ia determinants on human $\mathrm{T}$ cell subsets defined by monoclonal antibody: activation stimuli required for expression. J Exp Med 1979; 150: 1472-82.

23 Uchiyama T, Nelson D L. Fleisher T A, Waldmann T A. A monoclonal antibody (anti-Tac) reactive with activated and functionally mature human T cells. II. Expression of Tac antigen on activated cytotoxic killer $T$ cells, suppressor cells, and one of the two types of helper T cells. J Immunol 1981; 126: 1398-403.

24 Tsudo $M$, Uchiyama $T$, Uchino $H$. Expression of Tac antigen on activated normal human B cells. J Exp Med 1984; 160: 612-7.

25 Trowbridge I S, Omary M B. Human cell surface glycoprotein related to cell proliferation is the receptor for transferrin. Proc Natl Acad Sci USA 1981; 78: 3034-43.

26 Haynes B F, Hemler M E, Mann D L, et al. Characterization of a monoclonal antibody (4F2) that binds to human monocytes and to a subset of activated lymphocytes. $J$ Immunol 1981; 126: 1409-14.

27 Nykänen P, Bergroth V, Raunio P, Nordström D, Konttinen Y T. Phenotypic characterization of in vitro proliferating cells in rheumatoid arthritis synovial membrane. Rheumatol Int 1986; 6: $269-71$.

28 Ishikawa $\mathbf{H}$, Ziff $\mathbf{M}$. Electron microscopic observations of immunoreactive cells in the rheumatoid synovial membrane. Arthritis Rheum 1976; 19: 1-14.

29 Fox R I, Theofilopoulos A N, Altman A. Production of interleukin 2 (IL 2) by salivary gland lymphocytes in Sjögren's syndrome. Detection of reactive cells by using antibody directed to synthetic peptides of IL 2. J Immunol 1985; 135: 3109-15. 